\section{Biochemistry texts}

\section{E.D. Saggerson}

Elementary Biochemistry: An Introduction to the Chemistry of Living Cells. By Julian Davies and Barbara Shaffer Littlewood. Pp.346. (PrenticeHall, Englewood Cliffs: New Jersey and Hemel Hempstead, UK, 1979.) Biochemistry. By F.B. Armstrong and T.P. Bennett. Pp.491. (Oxford University Press: Oxford, 1979.) £14.

THE stated objective of Davies and Littlewood is to show "that biochemistry is fun" in a book aimed at students not specialising in biochemistry. Whether it is fun or not, the result is a fine book that would make an adequate textbook for any student whose course does not demand the mastery of one of the larger standard textbooks or who wants firstly to read a simpler account of the general features of the subject.

The book, consisting of 16 chapters, has 346 pages of quite small print. The style is simple and attractive and the figures are clear. The scope of the book is quite wide, opening with a chapter on cell structure and organisation, organic biomolecules and the elemental composition of cells. Three chapters are then devoted to protein structure and properties, determination of protein structure (protein separation, sequence determination, X-ray crystallography) and a simple description of enzyme function. The chapter on enzymes does not make recourse to a single equation but manages to describe the salient features of enzyme action together with sections dealing with the use of enzymes in medical diagnosis, industrial uses of enzymes, and enzyme inhibitors. The latter section is interesting since the actions of a number of poisons are discussed together with the actions of a number of antibiotics as enzyme inhibitors.

The general features of intermediary metabolism are covered in approximately 120 pages including, in the section on lipids, discussion of membranes, lipoproteins and the involvement of lipids in heart disease. Two chapters are devoted to nucleic acid structure, transcription and translation including a small section on the use of recombinant DNA in 'genetic engineering'. Human genetic diseases are also briefly considered in this part of the book. Regulation and control are specifically dealt with in a separate chapter which introduces the concept of the operon using the control of the expression of the lac operon as an example, briefly considers regulation of enzyme activity and contains a section on hormones. This latter section, which considers plant hormones and pheromones as well as mammalian hormones, is probably too brief and superficial to deal adequately with the topic but does contain some useful summary tables of hormone structure, source, effect and symptoms of excess or deficiency. The final two chapters in the book are unusual for an elementary biochemistry text. One deals with viruses (structure, life cycle and possible involvement in cancer), the other with antimicrobial agents. There is also an appendix setting out some important aspects of organic chemistry that are relevant to biochemical reactions.

In conclusion, the authors have done well in producing a very sound book which may well appeal to a wide readership.

Armstrong and Bennett's is a general textbook on the subject containing more material than the book by Davies and Littlewood but considerably less than the established textbooks by Lehninger, McGilvery, Stryer, and so on. 467 pages are contained in 24 chapters but the quantity of text on each page being quite small together with a large number of figures means that the content is less than at first sight. The contents include the history of biochemistry, protein structure, simple enzyme kinetics, carbohydrate, lipid and nucleic acid structure (one chapter on each), coenzyme function, six chapters on metabolism (including one on the basics of human nutrition), a chapter on hormones, and three chapters covering molecular. genetics and protein synthesis.

The text is clearly and concisely presented and the figures are good. However, I found the index rather incomplete and there are some serious omissions in the section on intermediary metabolism. Certain aspects of lipid metabolism in particular are grossly neglected. I could find no sections dealing with fatty acid and sterol biosynthesis or with ketone body metabolism. Glycogen metabolism is barely mentioned except when its regulation is used as an example of hormonal control. Gluconeogenesis also received scant attention with no consideration of its physiological role.

Priced at $£ 14$, I do not feel that this book will be competitive on the student market.

David Saggerson is Lecturer in Biochemistry at University College London, UK.

\section{Food provision and energy resources}

Food Energy and Society. By D. and M. Pimentel. Pp.165. (Edward Arnold: London, 1979.) Paperback £3.95.

THE dependence of food provision for man on sources of energy other than contemporary sunshine has been dealt with in a spate of books and articles published in recent years. The Pimentels' book,

\section{K.L. Blaxter}

through numerous examples in the text and in tabular form, provides a wider basis of illustration of this dependence than most and in so doing a wider perspective. It is designed for undergraduate teaching and will be useful. Indeed, as much of the information quoted is given in original units, it will provide undergraduates with useful exercises in conversion of units to a common basis.

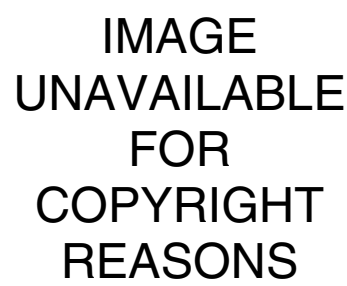

